\title{
Empirical Research on Relationship between Entrepreneurial Resource, Strategy and Performance under Different Environment
}

\author{
Shaozhong $\mathrm{Yu}^{1}$ and Le Zhang ${ }^{1,2,3, *}$ \\ ${ }^{1}$ College of Economics, Zhejiang University, Hangzhou, China, 310027 \\ ${ }^{2}$ School of Finance, Zhejiang University of Finance \& Economics, Hangzhou, \\ China, 310018 \\ ${ }^{3}$ China Academy of Financial Research, Zhejiang University of Finance \& \\ Economics, Hangzhou, China, 310018 \\ yszzju@zju.edu.cn,zhangle@zufe.edu.cn
}

\begin{abstract}
In this paper, we introduce environmental dynamism as the contextual factor, and conduct an empirical research on relationship of entrepreneurial resource, strategy and performance. We find that entrepreneurial resources including financial resources, human resources, management resources, information resources, technological resources, policy resources have a markedly positive impact on entrepreneurial performance, and the importance order is human resources, financial resources, information resources, technological resources, policy resources, management resources. These resources also have positive impact on entrepreneurial strategy; the richer the financial resources, human resources, information resources are, the easier it is to implement entrepreneurial strategy including cost leadership strategy and differentiation strategy; the richer the management resources are, the easier it is to implement cost leadership strategy; the richer the technological are, policy resources are, the easier it is to implement differentiation strategy. The cost leadership strategy has a lower significant impact on entrepreneurial performance compared with the differentiation strategy, and these strategies all play a partial mediating effect between entrepreneurial resource and entrepreneurial performance. Environmental dynamism plays a negative effect on the influence of financial resources, human resources, management resources, and policy resources on entrepreneurial performance and plays a positive effect on the influence of information resources, technological resources on entrepreneurial performance. Finally, we present research conclusion, trends and perspectives.
\end{abstract}

Keywords: entrepreneurial resources, entrepreneurial strategy, environmental dynamic, entrepreneurial performance

\section{Introduction}

With the advent of the entrepreneurial economy in the 21st century, a plenty of entrepreneurial activities have emerged all over the world. Researches related entrepreneurship have drawn attention from both theoretical field and practical field, which attract international researchers from economics field, management fields, sociology field, organizational behavior field, population ecology and other fields to study in this subject. Their studies over this topic triggered a series of thinking in entrepreneurial related fields and have promoted the development of entrepreneurial studies.

However, in existing entrepreneurship studies, few researchers dive deep into the development of start-up companies from the perspective of resources and strategy 
formulation. For some specific entrepreneurial enterprises, it is crucial to choose developing strategy based on its limited resources and entrepreneurial purpose, the study on them was not given full attention to as different reasons. In fact, entrepreneurial resources, strategy and efficiency themselves are all the key points in entrepreneurship research, but studies over these problems are always isolated from each other and few studies integrate these factors systematically and quantitatively. Under this background, this paper tentatively studied from the contingent perspective and did empirical research on relationship of entrepreneurial resource, strategy and performance under different environment. There is no doubt that this research would be great complement and extension to the existing entrepreneurial theory. Also this research offers important practical directions for startups to promote its growth and continuous development by making strategies timely with its limited resources.

\section{Literature Review, Modelling and Hypothesis}

In existing research results concerning the impact of entrepreneurial resources on strategic practice and efficiency, many researchers emphasis on the direct influence of resources on entrepreneurial efficiency. Stinchcombe pointed out that entrepreneurial enterprises usually have a high rate of failure for multiple reasons: limited resources; members of the organization cannot quickly adapt to new roles and working relationships; lack of credit record between external buyers and vendors etc. Rich starting-up resources, especially rich working and entrepreneurial experience, would help entrepreneurial enterprises overcome the shortcomings of new to market, and thus improve the performance of entrepreneurial enterprises [1]. Pfeffer and Salancik believed resources are the important basis for enterprises building their own competitive advantages. Resources are crucial to the survival and development of enterprises, especially to startups, because they all need necessary resources to survive from the task environment. The development of entrepreneurial companies relies on the efficiency of gaining external resources to great extent [2]. Chandler and Hanks found out that the more resources entrepreneurial enterprises integrate, the better the resources foundation is; the greater chance the starting-up enterprises would have to survive and develop; and thus better performance the entrepreneurial companies would have [3]. That is, the scale and performance of startups rely on the resources conditions entrepreneurs create. The more resources startups would have and the more heterogeneous the resources integrate, the greater the strength and performance they would have. In this competitive and complicated market, limited resources has become the biggest obstacle to the survival and growth of startups [4]. Abundant entrepreneurial resources could promote entrepreneurial activities directly [5-6]. Zahra and George pointed out that entrepreneurial resources have directly impact on the degree; speed and scale of the business of startups, besides the resources could also promote the competitive advantages and performance of entrepreneurial enterprises [7]. Colombo and Grili reported that previous industry experience, knowledge and networks can affect the performance of entrepreneurial activities positively [8].

Other researchers tend to believe that entrepreneurial resources affect startups performance by influencing its strategic decisions. For example, Timmons pointed out that entrepreneurial resources are the supporting element in the process of starting a business[9]. Entrepreneurs usually endeavor to design delicate and cost cautious entrepreneurial strategies to make the best of resources. These strategies are crucial to entrepreneurial enterprises and would directly affect the performance of entrepreneurial performance. Both reported entrepreneurial resources affects and determines the entrepreneurial startups strategies [10-11]. The choices and practices of entrepreneurial strategies affect the performance of startups. Hmieleski and Corbett studied entrepreneurial strategy decisions under different entrepreneurial resources abundant and 
opportunities novelty situations. According to their studies, when resources and novel entrepreneurial opportunities are limited, entrepreneurs tend to adopt heuristics methods. But the entrepreneurial opportunities are at high level of novelty, improvisation would become the most possible way of actions and decisions. When resources are rich but novelty of entrepreneurships is at low level, entrepreneurs would have enough conditions to make strategic plans and would appear to behave in strategic ways [12].

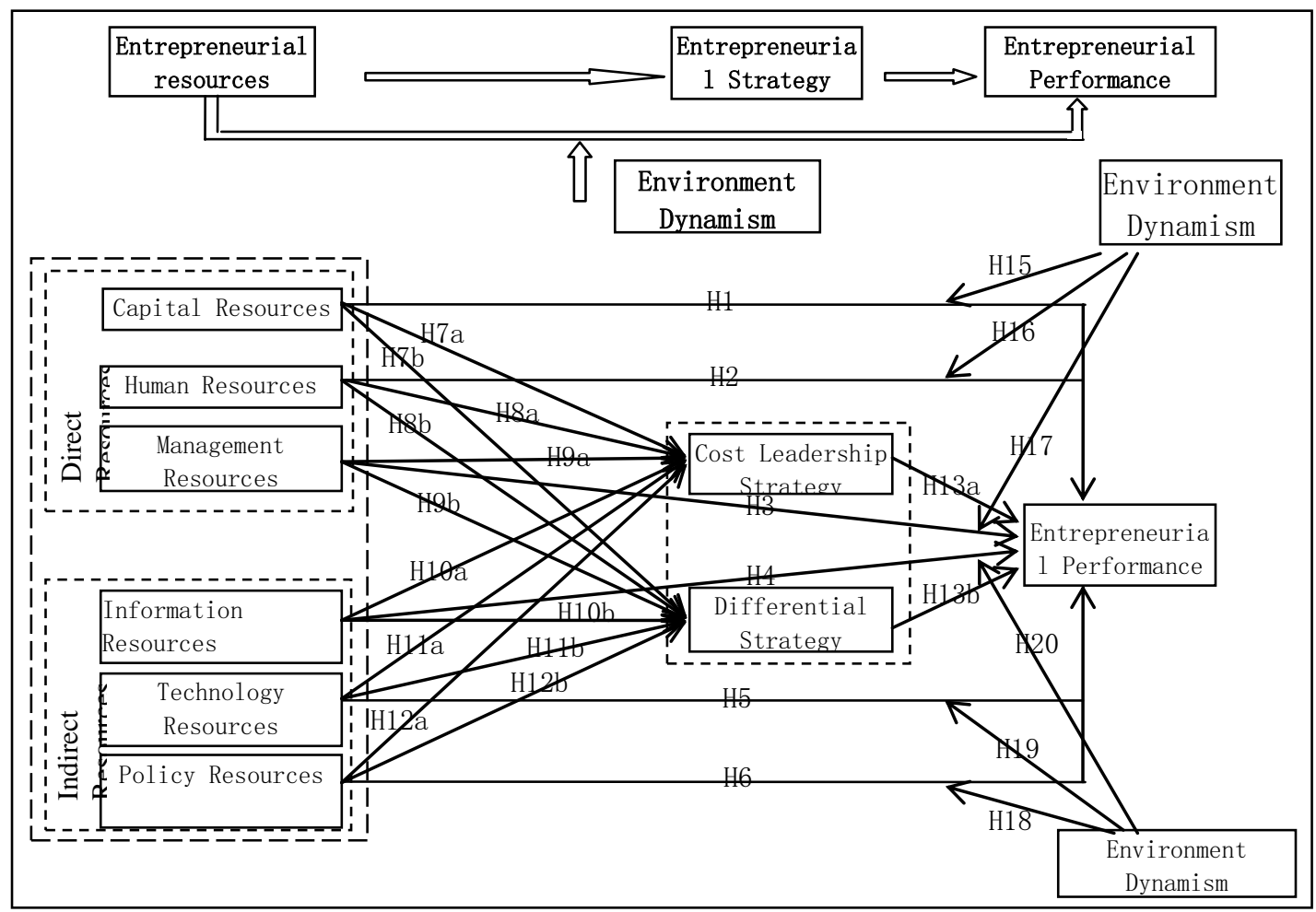

Figure 1. Model Base on Hypothesis

Besides, many scholars studied the adjustment effect of dynamic environment. After doing empirical analysis over 102 manufactories, Zahra report that entrepreneurial and innovative factors (including entrepreneurial resources) have positive impact on the entrepreneurial performance. Also the dynamic of environment exert important adjust function to these two factors [13]. Lumpkin and Dess, Lumpkin and Sloat built a contingency theory framework. They also analyzed the adjustment function of environment of entrepreneurial resources and directions that influence the entrepreneurial performance. They pointed out that high performance of entrepreneurial enterprises is the result of efficient matching of this factors and environmental dynamics [14-16]. Zahra and George reported that organizational factors affect the development of international entrepreneurial business. Environmental dynamic becomes the contingency variable of the relationship between organizational resources and entrepreneurial business. Organizations adjust their behaviors and decisions according to environmental dynamic changes, which could promote organizational factor's influence in the scale, speed, range and performance of international entrepreneurial business. Kreiser, Marino and Weaver proved in their research the adjust function of environmental dynamic. Under low level of environmental dynamic, entrepreneurial enterprises improve their level of risk tolerance and resources are also easier to get, which could be an incentive to the performance of entrepreneurial activities [17]. Wiklund and Shepherd include environmental dynamics as the contingency variable in his research and reported that under dynamic environment, the status of consumers and competitors is unpredictable, and market tend to be more 
innovative and flexible [18]. In this case, information and technology would be difficult to get, which is bad for entrepreneurs to take the risk and promote performance. Ensley, Pearce and Hmieleski introduced environmental dynamic to their study of entrepreneurs' behavior and performance of entrepreneurial enterprises. In this study, they find environmental dynamics play an important adjustment function [19].

Based on these previous research results, and according to studies of Timmons [9], Lin Song [20], Yao Meifan, Huang Jinrui, Zhang Xuyang [21] on deconstructing entrepreneurial resources into direct resources and indirect resources, and referring to research of Porter on typical division of competitive entrepreneurial strategies [22], but considering that target-oriented strategies which achieve differentiation by satisfying the special needs of specific target or accomplish low cost while serve this object, are all achieved by differentiation strategy or cost leadership strategy, this paper built a model as shown in picture 1 considering capital, human resources, management resources, information, technology, policy resources as influential factors, entrepreneurial strategy as intermediary factors, environmental dynamics as adjust factor and performance of entrepreneurial business strategy as influential result. The hypothesis is as follows

\section{Table 1. Summary of Hypothesis}

\begin{tabular}{|c|c|}
\hline No. & Descriptions of Hypothesis \\
\hline \multicolumn{2}{|r|}{ Hypothesis between entrepreneurial resources and entrepreneurial performance } \\
\hline H1 & $\begin{array}{l}\text { Hypothesis 1: Capital resources have positive impact on entrepreneurial performance. The richer } \\
\text { the capital is, the more beneficial it is to promote entrepreneurial performance. }\end{array}$ \\
\hline $\mathrm{H} 2$ & $\begin{array}{l}\text { Hypothesis2: Human resources have positive impact on entrepreneurial performance. The richer } \\
\text { human resources are, the more it is to promote entrepreneurial performance. }\end{array}$ \\
\hline $\mathrm{H} 3$ & $\begin{array}{l}\text { Hypothesis3: Management resources have positive impact on entrepreneurial performance. The } \\
\text { richer the management resources are, the more beneficial it is to promote entrepreneurial } \\
\text { performance. }\end{array}$ \\
\hline $\mathrm{H} 4$ & $\begin{array}{l}\text { Hypothesis4: Information resources have positive impact on entrepreneurial performance. The } \\
\text { richer the information resources are, the more beneficial it is to promote entrepreneurial } \\
\text { performance. }\end{array}$ \\
\hline H5 & $\begin{array}{l}\text { Hypothesis5: Technology resources have positive impact on entrepreneurial performance. The } \\
\text { richer the technology resources are, the more beneficial it is to promote entrepreneurial } \\
\text { performance. }\end{array}$ \\
\hline H6 & $\begin{array}{l}\text { Hypothesis6: Policy resources have positive impact on entrepreneurial performance. The richer the } \\
\text { policy resources the more beneficial to promote entrepreneurial performance. }\end{array}$ \\
\hline \multicolumn{2}{|r|}{ Hypothesis among entrepreneurial resources, entrepreneurial strategy and performance } \\
\hline \multirow{2}{*}{$\mathrm{H7}$} & $\begin{array}{l}\text { Hypothesis7a: Capital resources have positive impact on cost leadership strategy. The richer the } \\
\text { capital resources are, the more beneficial it is to make and carry out cost leadership strategy. }\end{array}$ \\
\hline & $\begin{array}{l}\text { Hypothesis } 7 b \text { : Capital resources have positive impact on differential strategy. The richer the capital } \\
\text { resources are, the more beneficial make and carry out differential strategy. }\end{array}$ \\
\hline \multirow{2}{*}{ H8 } & $\begin{array}{l}\text { Hypothesis8a: Human resources have positive impact on cost leadership strategy. The richer the } \\
\text { human resources are, the more beneficial it is to make and carry out cost leadership strategy. }\end{array}$ \\
\hline & $\begin{array}{l}\text { Hypothesis8b: Human resources have positive impact on differential strategy. The richer resources } \\
\text { are, the more beneficial it is to make and carry out differential strategy. }\end{array}$ \\
\hline \multirow[t]{2}{*}{ H9 } & $\begin{array}{l}\text { Hypothesis9a: Management resources have positive impact on cost leadership strategy. The richer } \\
\text { the management resources are, the more beneficial it is to make and carry out cost leadership } \\
\text { strategy. }\end{array}$ \\
\hline & $\begin{array}{l}\text { Hypothesis9b: Management resources have positive impact on differential strategy. The richer the } \\
\text { management resources are, the more beneficial it is to make and carry out differential strategy. }\end{array}$ \\
\hline \multirow[t]{2}{*}{$\mathrm{H} 10$} & $\begin{array}{l}\text { Hypothesis10a: Information resources have positive impact on cost leadership strategy. The richer } \\
\text { the information resources are, the more beneficial it is to make and carry out cost leadership } \\
\text { strategy. }\end{array}$ \\
\hline & $\begin{array}{l}\text { Hypothesis10b: Information resources have positive impact on differential strategy. The richer the } \\
\text { information resources are, the more beneficial it is to make and carry out differential strategy. }\end{array}$ \\
\hline \multirow[t]{2}{*}{ H11 } & $\begin{array}{l}\text { Hypothesis11a: Technology resources have positive impact on cost leadership strategy. The richer } \\
\text { the technology resources are, the more beneficial it is to make and carry out cost leadership strategy. }\end{array}$ \\
\hline & Hypothesis11b: Technology resources have positive impact on differential strategy. The richer the \\
\hline
\end{tabular}




\begin{tabular}{|c|c|}
\hline & nology resources are, the more beneficial it is to make and carry out differential strategy. \\
\hline \multicolumn{2}{|r|}{ Hypothesis of relationship among entrepreneurial resources, strategy and performance } \\
\hline \multirow{2}{*}{$\mathrm{H} 12$} & $\begin{array}{l}\text { Hypothesis12a: Policy resources have positive impact on cost leadership strategy. The better the } \\
\text { policy resources are, the more beneficial it is to make and carry out cost leadership strategy. }\end{array}$ \\
\hline & $\begin{array}{l}\text { Hypothesis12b: Policy resources have positive impact on differential strategy. The better the policy } \\
\text { resources are, the more beneficial it is to make and carry out differential strategy. }\end{array}$ \\
\hline \multirow{2}{*}{ H13 } & $\begin{array}{l}\text { Hypothesis13a: If cost leadership strategy has positive influence, the more efficiently they make } \\
\text { and carry out cost leadership strategy, the more beneficial it is to promote the performance of } \\
\text { entrepreneurial performance. }\end{array}$ \\
\hline & $\begin{array}{l}\text { Hypothesis } 13 \mathrm{~b} \text { : If differential strategy has positive influence, the more efficiently they make and } \\
\text { carry out differential strategy, the more beneficial it is to promote the performance of } \\
\text { entrepreneurial performance. }\end{array}$ \\
\hline \multirow{2}{*}{$\mathrm{H} 14$} & $\begin{array}{l}\text { Hypothesis14a: Cost leadership strategy plays intermediary roles whilst entrepreneurial resources } \\
\text { indirectly affect entrepreneurial performance. }\end{array}$ \\
\hline & $\begin{array}{l}\text { Hypothesis14b: Differential strategy plays intermediary roles whilst entrepreneurial resources } \\
\text { indirectly affect entrepreneurial performance. }\end{array}$ \\
\hline \multicolumn{2}{|r|}{ Hypothesis of relationship among environmental dynamic adjustment, resources and performance } \\
\hline H15 & $\begin{array}{l}\text { Hypothesis15: Environmental dynamics have negative adjustment function, the higher level the } \\
\text { environmental dynamic is, the easier it is to weaken the positive impact of capital resources. }\end{array}$ \\
\hline H16 & $\begin{array}{l}\text { Hypothesis16: Environmental dynamics have negative adjustment function, the higher level the } \\
\text { environmental dynamic is, the easier it is to weaken the positive impact of capital resources. }\end{array}$ \\
\hline H17 & $\begin{array}{l}\text { Hypothesis 17: Environmental dynamics have negative adjustment function, the higher level the } \\
\text { environmental dynamic is, the easier it is to weaken the positive impact of management resources. }\end{array}$ \\
\hline H18 & $\begin{array}{l}\text { Hypothesis18: Environmental dynamics have negative adjustment function, the higher level the } \\
\text { environmental dynamic is, the easier it is to weaken the positive impact of information resources. }\end{array}$ \\
\hline H19 & $\begin{array}{l}\text { Hypothesis19: Environmental dynamics have negative adjustment function, the higher level the } \\
\text { environmental dynamic is, the easier it is to weaken the positive impact of technical resources. }\end{array}$ \\
\hline $\mathrm{H} 20$ & $\begin{array}{l}\text { Hypothesis20: Environmental dynamics have negative adjustment function, the higher level the } \\
\text { environmental dynamic is, the easier it is to weaken the positive impact of policy resources. }\end{array}$ \\
\hline
\end{tabular}

\section{Statistics and Methodology}

\subsection{Design of Questionnaire}

This questionnaire was designed by: (1) carding and reading domestic and abroad relating theories and empirical studies, and referencing their methodologies of designing questionnaires and some items of their measurement table, to design this paper's questionnaire at the first stage; (2) sufficient discussion with classmate and members of research team to modify and adjust the questionnaire; (3) sample testing over 14 enterprises, including Hangzhou Silan microelectronics Limited by Share, ABON Biopharm(Hangzhou) Co., Ltd, Hikvision Digital Technology Co., Ltd., Hangzhou Rongli Biopharm Co., Ltd., Hangzhou SDIC Microelectronics Co., Ltd., Hangzhou Weiou Biopharm Co., Ltd., etc. , collecting suggestions , modifying and optimizing the specific description and phraseology of the questionnaires accordingly. Then we structure the questionnaires. The basic information in the questionnaires is gathered using common question-and-answer content description. Fillers fill out forms by writing or choosing from multiple answers. Interpretation, explanation, intermediate, moderator variables adopt Likert seven rating scale.

\subsection{Measurement of Variables}

1. Entrepreneurial performance is the explained variable. To improve the scientificity and accuracy of the measurement, in this paper, we select multiple indicators (including profit-seeking indicators, growth indicators and sentiment indicators)to reflect the overall entrepreneurial performance and design 10 questions : "Compared to competitors, your company have : (1) higher sales growth rate (2) higher sales profit growth rate (3)higher assets and earnings growth rate (4) higher growth rate of return on investment(5)market 
share growth rate (6) higher workforce growth rate (7) low employee absence rate and dismission rate, and high employee retention rate (8) high employee loyalty and sentiment (9) high customer retention rate (customers are willing to buy your product constantly and your new product and service) (10) high credit in consumers' mind ( consumers are willing to give improvement suggestions for your product or service)

2. Entrepreneurial resources are explaining variables. According to the content and purpose of this research, entrepreneurial resources are divided into capital resources, human resources, management resources, information resources, technology resources and policy resources. For capital resources, 4 questions were designed : (1) self-funded capital is rich at the beginning stage (2) have abundant cash flows and could use it flexibly (3) have multiple capital gathering channels (4) easy to get external capital support, such as fund, loan and investment. For human resources, we set up the four questions as follows: (1) Talent people with foresight, innovation consciousness and innovation ability of entrepreneurial; (2) Highly educated and comprehensive talent people with variety of professional and knowledge background; (3) entrepreneurial team with highly entrepreneurship spirit and teamwork spirit; (4) variety of high-quality personnel easily to be hired from outside. For management resources, we set up three questions as follows: (1) entrepreneurial personnel have some entrepreneurial experience and management experience; (2) already have more advanced entrepreneurial management knowledge system; (3) easy to obtain variety management consulting and planning services from the outside. For information resources, we set up four questions as follows: (1) easy to obtain the relevant information of the industry your company is in or to be in; (2) easy to obtain the information of competitors, market and demand; (3) easy to obtain some public or proprietary products and technical information;(4) possess the information of research and development, purchasing, manufacturing marketing and service. For technology resources, we set up three questions as follows: (1) possess scientific and technological achievements project and even three types of patents; (2) easy to obtain variety of science and technology help and achievement from outside. (3) Build the platform for transformation of scientific and technological achievements, which can realize the commercialization of scientific and technological achievements. For policy resources, we set up three questions as follows: (1) Founded on the government investment and financing, the fiscal and taxation preferential policy and tilt; (2) the government has developed practical policy of entrepreneurship training and coaching when founded; (3) the government has developed a superior entrepreneurial talent introduction policy when founded.

3. Intermediary variable is the entrepreneurial strategy. According to the content and purpose of this article, the intermediary variable is deconstructed into Cost leadership strategy and Differentiation strategy. To measure the cost leadership strategy, We set up four questions as follows: (1) Vigorously implement the strategy of market coverage and penetration; (2) pushing the pricing strategy of the commendation;(3) PAY Attention to and implement the low-cost sales promotion strategy.(4) Pay attention to take the initiative to positive compete, trying to realize sustainable development in the fierce competition. To measure the differentiation strategy, we set up four questions as follows: (1) Focusing on the market segmentation and product positioning strategy; (2) Focusing on product and process innovation strategy; (3) Be in the lead In product and process innovation degree and speed with the competitors in the same industry; (4) Tend to take the initiative to implement innovation, seek different development in the competition.

4. Regulating variable dynamics is the environment, we set up the four corresponding questions as follows: (1) The speed of technical variation in business field is rapid, and new business may come very soon. (2) Customer preferences within the industry are changing rapidly. (3) Your company's customer demand changes rapidly and tends to look for new products and services. (4) Competitors continue to adjust the strategy and launch new products and services. 


\subsection{Collection of the Sample Data}

We choose the high-tech entrepreneurial enterprises as the respondents in China's Yangtze river economic and technological development zones and high-tech industrial development zone (the economic sector of HangJiahu, YongTaiwen, ShaoJinqu from Zhejiang province, the SuXichang, NingZhenyang economic sector from Jiangsu province, and Minhang economic and technological development zone, CaoHejing hightech development zone, Hongqiao economic and technological development zone and the Zhangjiang high-tech park from Shanghai). We gave out 580 questionnaires and took back 413 ones from March 2012 to July 2012 through on-the-spot interviews, fax, e-mail and mail. The recovery is $71.21 \%$, and the effective recovery is $62.24 \%$ after we got rid of 29 ones with too much blanks and 23 nonstandard ones with 361 effective ones left.

\subsection{Selection of Research Method}

It is particularly important to take scientific and reasonable method in order to improve and guarantee the accuracy and reliability of the results of the analysis. Suitable study methods to this research are Cronbach's Coefficient Alpha method, Factor Analysis method, Structural Equation Modeling method and Multiple Linear Regression Analysis method.

\section{Empirical Analysis}

\subsection{Reliability and Validity Test}

Results of reliability test, KMO sampling test and Bartlett sphere inspection are shown in table 2. As can be seen in table 2, the Cronbach's Coefficient Alphas of capital resources, human resources, management resources, information resources, technology resources, policy resources, cost leadership strategy, differential strategy, total entrepreneurial resources, total entrepreneurial resources, total environment dynamics, total entrepreneurial performance are $0.857,0.811,0.793,0.782,0.804,0.838,0.846$, $0.865,0.826,0.883,0.874,0.869$ respectively, which are all bigger than 0.70 . These factors are of high confidential level, which indicates these factors passed the reliability test. The empirical test follows.

As can be seen in Table 2, the KMO statistics of all these factors are bigger than 0.7. The value of $\chi^{2}$ shows significance of these factors ( $\mathrm{p}$ values are zero and lower than 0.01 , which is significant at the 0.01 confidential level). Therefore factor analysis method is adopted. By doing factor analysis, the results show in table3 and table4. From table 3, characteristic values, 4.975, 3.843, 2.396, 1.874, 1.387, 1.178 are all bigger than 1 , which indicate that there are 6 factors with characteristics value over 1 . The probabilities of these factors are $21.826 \%, 17.182 \%, 13.253 \%, 10.458 \%, 9.165 \%, 8.023 \%$, the joint probability reached $79.907 \%$, which suggest that these factors are of high explaining ability. Also as can be seen in table 4, questions of questionnaires are designed by the hypothesis of above factors. There is no cross load of these factors. Load value for one factor's questions are all bigger than 0.5, a standard brought up [23]. The reliability level is high, and thus passes the validity test. Subsequent further empirical analysis can be performed. 
Table2. Reliability Test, KMO Sample Measurement and Bartlett Sphere Inspection Results

\begin{tabular}{|c|c|c|c|c|c|c|}
\hline Variables & Items & $\begin{array}{c}\text { Cronbach's } \\
\text { Coefficient } \\
\text { Alpha }\end{array}$ & $\begin{array}{l}\text { High } \\
\text { reliability } \\
\text { reference } \\
\text { value }\end{array}$ & $\begin{array}{c}\text { KMO } \\
\text { Statistics }\end{array}$ & $\begin{array}{c}\text { KMO } \\
\text { Reference } \\
\text { value }\end{array}$ & $\begin{array}{c}\text { Bartlett } \\
\text { sphere } \\
\text { inspection } \\
\text { results } \mathrm{P} \\
\text { value }\end{array}$ \\
\hline $\begin{array}{l}\text { Total entrepreneurial } \\
\text { resources }\end{array}$ & 21 & 0.826 & \multirow{12}{*}{$\geq 0.7$} & 0.852 & \multirow{12}{*}{$\geq 0.7$} & 0.000 \\
\hline Capital resources & 4 & 0.857 & & 0.868 & & 0.000 \\
\hline Human resources & 4 & 0.811 & & 0.834 & & 0.000 \\
\hline Management resources & 3 & 0.793 & & 0.857 & & 0.000 \\
\hline Information resources & 4 & 0.782 & & 0.826 & & 0.000 \\
\hline Technology resources & 3 & 0.804 & & 0.885 & & 0.000 \\
\hline Policy resources & 3 & 0.838 & & 0.879 & & 0.000 \\
\hline $\begin{array}{c}\text { Entrepreneurial strategy } \\
\text { summery }\end{array}$ & 8 & 0.883 & & 0.807 & & 0.000 \\
\hline Cost leadership strategy & 4 & 0.846 & & 0.802 & & 0.000 \\
\hline Differential strategy & 4 & 0.865 & & 0.813 & & 0.000 \\
\hline $\begin{array}{l}\text { Environmental dynamic } \\
\text { summary }\end{array}$ & 4 & 0.874 & & 0.843 & & 0.000 \\
\hline $\begin{array}{l}\text { Entrepreneurial Performance } \\
\text { Summary }\end{array}$ & 10 & 0.869 & & 0.851 & & 0.000 \\
\hline
\end{tabular}

Table 3. Total Variance

\begin{tabular}{|c|c|c|c|c|c|c|}
\hline \multirow{2}{*}{$\begin{array}{c}\text { Principle } \\
\text { component }\end{array}$} & \multicolumn{3}{|c|}{ Initial Eigenvalues } & \multicolumn{3}{c|}{ Factor Extraction Results } \\
\cline { 2 - 6 } & Total & $\begin{array}{c}\text { Percentage of } \\
\text { total (\%) }\end{array}$ & $\begin{array}{c}\text { Accumulated } \\
\text { percentage (\%) }\end{array}$ & Total & $\begin{array}{c}\text { Percentage of } \\
\text { total }(\%)\end{array}$ & $\begin{array}{c}\text { Accumulated } \\
\text { percentage }(\%)\end{array}$ \\
\hline 1 & 4.975 & 21.826 & 21.827 & 4.975 & 21.826 & 21.827 \\
2 & 3.843 & 17.182 & 39.008 & 3.843 & 17.182 & 39.008 \\
3 & 2.396 & 13.253 & 52.261 & 2.396 & 13.253 & 52.261 \\
4 & 1.874 & 10.458 & 62.719 & 1.874 & 10.458 & 62.719 \\
5 & 1.387 & 9.165 & 71.884 & 1.387 & 9.165 & 71.884 \\
6 & 1.178 & 8.023 & 79.907 & 1.178 & 8.023 & 79.907 \\
7 & 0.861 & 6.986 & 86.893 & & & \\
8 & 0.529 & 5.899 & 92.792 & & & \\
9 & 0.354 & 4.467 & 97.259 & & & \\
10 & 0.212 & 2.741 & 100 & & & \\
\hline
\end{tabular}

Table 4. Rotating Factor Loading Coefficient Value

\begin{tabular}{|c|c|c|c|c|c|c|c|}
\hline \multirow[t]{2}{*}{ Variable } & \multirow{2}{*}{$\begin{array}{l}\text { Measurement } \\
\text { Item }\end{array}$} & \multicolumn{6}{|c|}{ Factor loading coefficient (after rotation) } \\
\hline & & 1 & 2 & 3 & 4 & 5 & 6 \\
\hline \multirow{4}{*}{$\begin{array}{l}\text { Capital Resources } \\
\text { (CR) }\end{array}$} & CR1 & .174 & .183 & .098 & .282 & .158 & .724 \\
\hline & CR2 & .208 & .237 & .107 & .334 & .114 & .675 \\
\hline & CR3 & .117 & .309 & .146 & .215 & .086 & .632 \\
\hline & CR4 & -.125 & .284 & -.081 & .159 & .179 & .691 \\
\hline \multirow{4}{*}{$\begin{array}{l}\text { Human Resources } \\
\text { (HR) }\end{array}$} & HR1 & .171 & .094 & .643 & .156 & -.101 & .097 \\
\hline & HR2 & .129 & -.088 & .669 & .143 & .092 & .083 \\
\hline & HR3 & .156 & .153 & .692 & .213 & -.074 & .121 \\
\hline & HR4 & .237 & .131 & .657 & .178 & .079 & .148 \\
\hline \multirow{3}{*}{$\begin{array}{c}\text { Management } \\
\text { Resources (MR) }\end{array}$} & MR1 & .716 & .145 & .274 & .189 & .058 & -.067 \\
\hline & MR2 & .683 & -.089 & .186 & .143 & .115 & .102 \\
\hline & MR3 & .654 & -.113 & .233 & .172 & .136 & .141 \\
\hline \multirow{2}{*}{$\begin{array}{c}\text { Information } \\
\text { Resources (IR) }\end{array}$} & IR1 & .124 & .184 & -.097 & .306 & .805 & .197 \\
\hline & IR2 & .193 & .165 & .132 & .265 & .784 & .152 \\
\hline
\end{tabular}




\begin{tabular}{|c|c|c|c|c|c|c|c|}
\hline \multirow{2}{*}{ Variable } & Measurement & \multicolumn{7}{|c|}{ Factor loading coefficient (after rotation) } \\
\cline { 2 - 7 } & Item & 1 & 2 & 3 & 4 & 5 & 6 \\
\hline \multirow{3}{*}{$\begin{array}{c}\text { Technology } \\
\text { Resources (TR) }\end{array}$} & IR3 & -.139 & .284 & .163 & .183 & .823 & .259 \\
\cline { 2 - 7 } & IR4 & .233 & .241 & .118 & -.164 & .791 & .130 \\
\cline { 2 - 7 } & TR1 & .256 & .758 & .223 & -.145 & .135 & .198 \\
\hline \multirow{2}{*}{$\begin{array}{c}\text { Policy Resources } \\
\text { (PR) }\end{array}$} & TR3 & .194 & .735 & .201 & .166 & .151 & .275 \\
\cline { 2 - 7 } & PR1 & .149 & .695 & .163 & -.131 & .109 & .302 \\
\cline { 2 - 7 } & PR2 & .078 & .257 & -.151 & .819 & .197 & .216 \\
\hline
\end{tabular}

Note: In factor analysis, extract factor by principal component method and rotate by maximum variance method; detail descriptions for each items of each measurement can be found in the part of explaining variables measurement.

\subsection{Structure Equation Modelling Analysis and Test Results of Entrepreneurial Resources, Entrepreneurial Strategy and Entrepreneurial Performance}

Fitting analysis and hypothesis test of structure equation model are done by AMOS 7.0 software. Results are shown in table 5 and table 6 . As can be seen in table5, Fitting Index of Structural Equation Model table, the values of $\chi 2 / \mathrm{df}$ of entrepreneurial resources, entrepreneurial strategy, and entrepreneurial performance are 1.947, 2.258, 1.683 respectively. The values are all smaller than 3 . The result satisfied reference standard of high goodness of fitting that brought up by Bagozzi, Yi and Singh [24], Hair et al. [23] The values of $\chi 2 / \mathrm{df}$ are all smaller than 3 and $\mathrm{p}$ values are all zero and smaller than0.05. The result satisfied reference standard of high goodness of fitting that brought up by $\mathrm{Hu}$ and Bentler [25]. Values of NFI are 0.932, 0.954, 0.946 respectively, and values of NNFI are $0.941,0.962,0.955$ respectively. CFI values are $0.944,0.967$, and 0.961 respectively. The value of NFI, NNFI and CFI of these three factors are all bigger than 0.90, which satisfied reference standard of high goodness of fitting that brought up [26-27]. And for $\mathrm{NFI} \geqq 0.90, \mathrm{NNFI} \geqq 0.90, \mathrm{CFI} \geqq 0.90 \mathrm{RMSEA}$ are $0.064,0.053,0.056$ respectively lower than 0.08 , which satisfied the reference standard of high goodness of fitting that brought up [28] [25]. All these test results show the good fitness of this structure equation model.

As is shown in table 6, SEM causal path coefficient and hypothesis verification table, causal path coefficient of $\gamma_{\mathrm{CR} \text {-EP, }} \gamma_{\mathrm{HR}-\mathrm{EP},} \gamma_{\mathrm{MR} \text {-EP, }} \gamma_{\mathrm{IR} \text {-EP, }} \gamma_{\mathrm{TR} \text {-EP, }} \gamma_{\mathrm{PR} \text {-EP }}$ are $0.103,0.115,0.043$, $0.074,0.061$, and 0.052 respectively. The value of C.R. are all bigger than reference value"1.96". That is, capital resources, human resources, management resources, information resources, technology resources and policy resources could significantly improve the entrepreneurial performance, which consistent with hypothesis 1,2,3,4,5,6. Standardized causal path coefficients of $\gamma_{\mathrm{CR}-\mathrm{CLS}}, \gamma_{\mathrm{CR}-\mathrm{DS}}, \gamma_{\mathrm{HR}-\mathrm{CLS}}, \gamma_{\mathrm{HR}-\mathrm{DS}}, \gamma_{\mathrm{IR}-\mathrm{CLS}}, \gamma_{\mathrm{IR}-\mathrm{DS}}$ are $0.189,0.242,0.123,0.331,0.184,0.138$ respectively. C.R. value is bigger than the reference value "1.96". P values are all 0.000 which are smaller than 0.01 . These results indicate that statistics is significant under 0.01 confidential levels. That is, capital resources, human resources, information resources can all significantly promote the cost leadership strategy and differential strategy. This result is consistent with hypothesis $7 \mathrm{a}$, $7 \mathrm{~b}, 8 \mathrm{a}, 8 \mathrm{~b}, 10 \mathrm{a}$, and 10b. However, the standardized causal path coefficients of $\gamma_{\text {MR-CLS, }}$ $\gamma_{\text {MR-DS }}$ are $0.179,0.506$ respectively. C.R. values are $11.420>1.96,1.718<1.96$. P values are $0.000<0.01,0.517>0.01$. These results indicate that under 0.01 confidential level, management resources could significantly promote the design and implement of cost leadership strategy, but do not have positive impact over the differential strategy. This result is consistent with hypothesis 9a but is not consistent with 9b.The standardized causal path coefficients of $\gamma_{\text {TR-CLS, }} \gamma_{\text {TR-DS, }} \gamma_{\text {PR-CLS, }} \gamma_{\text {PR-DS }}$ are $0.482,0.237,0.398$, and 0.205 respectively. C.R. values are $1.659<1.96,12.526>1.96,1.473<1.96,12.178>1.96$. P values are $0.623>0.01,0.000<0.01,0.685>0.01,0.000<0.01$. This result indicate that under 0.01 confidential level, technology resources, policy resources could significantly 
promote the formulation and implementation of differential strategy, but do not have positive impact on the cost leadership strategy. This result is consistent with hypothesis11a, 12a, but is not consistent with 11b, $12 \mathrm{~b}$.

Table 5. Fitting Index of Structural Equation Model (SEM)

\begin{tabular}{|c|c|c|c|c|c|c|c|c|c|c|c|c|}
\hline \multirow[b]{2}{*}{ Variables } & \multicolumn{2}{|c|}{$\chi^{2 / d f}$} & \multicolumn{2}{|c|}{$\begin{array}{c}\text { Significan } \\
\text { ce } \\
\text { probability }\end{array}$} & \multicolumn{2}{|c|}{ NFI } & \multicolumn{2}{|c|}{ NNFI } & \multicolumn{2}{|c|}{ CFI } & \multicolumn{2}{|c|}{ RMSEA } \\
\hline & sta. & $\begin{array}{l}\text { Ref } \\
\text {.val }\end{array}$ & sta & $\begin{array}{l}\text { Ref. } \\
\text { val. }\end{array}$ & $\begin{array}{l}\text { sta } \\
\text {. }\end{array}$ & $\begin{array}{l}\text { Ref. } \\
\text { val. }\end{array}$ & sta. & $\begin{array}{l}\text { Ref. } \\
\text { val. }\end{array}$ & sta. & $\begin{array}{l}\text { Ref. } \\
\text { val. }\end{array}$ & sta. & $\begin{array}{l}\text { Ref. } \\
\text { val. }\end{array}$ \\
\hline $\begin{array}{l}\text { Entrepreneurial } \\
\text { Resources }\end{array}$ & $\begin{array}{l}1.9 \\
47\end{array}$ & \multirow{3}{*}{$\leq 3$} & $\begin{array}{l}0.0 \\
00\end{array}$ & \multirow{3}{*}{$\begin{array}{l}<0.0 \\
5\end{array}$} & $\begin{array}{l}0.9 \\
32\end{array}$ & \multirow{3}{*}{$\begin{array}{l}\geq 0.9 \\
0\end{array}$} & $\begin{array}{c}0.94 \\
1\end{array}$ & \multirow{3}{*}{$\begin{array}{c}\geq 0.9 \\
0\end{array}$} & $\begin{array}{c}0.94 \\
4\end{array}$ & \multirow{3}{*}{$\begin{array}{l}\geq 0.9 \\
0\end{array}$} & $\begin{array}{c}0.06 \\
4\end{array}$ & \multirow{3}{*}{$\begin{array}{l}\leq 0.0 \\
8\end{array}$} \\
\hline $\begin{array}{l}\text { Entrepreneurial } \\
\text { Strategy }\end{array}$ & $\begin{array}{l}2.2 \\
58\end{array}$ & & $\begin{array}{c}0.0 \\
00\end{array}$ & & $\begin{array}{l}0.9 \\
54\end{array}$ & & $\begin{array}{c}0.96 \\
2\end{array}$ & & $\begin{array}{c}0.96 \\
7\end{array}$ & & $\begin{array}{c}0.05 \\
3\end{array}$ & \\
\hline $\begin{array}{l}\text { Entrepreneurial } \\
\text { Performance }\end{array}$ & $\begin{array}{l}1.6 \\
83\end{array}$ & & $\begin{array}{c}0.0 \\
00\end{array}$ & & $\begin{array}{l}0.9 \\
46\end{array}$ & & $\begin{array}{c}0.95 \\
5\end{array}$ & & $\begin{array}{c}0.96 \\
1\end{array}$ & & $\begin{array}{c}0.05 \\
6\end{array}$ & \\
\hline
\end{tabular}

The standardized causal path coefficients of $\gamma_{\text {CLS-EP, }} \gamma_{\text {DS-EP }}$ are $0.257,0.282$ respectively. C.R. values are 13.051 and 13.674 which are all bigger than 1.96. P values are all $0.000<$ 0.01 . This result indicate that under 0.01 confidential level, cost leadership strategy and differential strategy could significantly promote entrepreneurial performance. This result is consistent with hypothesis13a, 13b. Besides, according to the path relationships displayed in table 4.12, we could draw the conclusion that cost leadership strategy and differential strategy could exert intermediary function while entrepreneurial resources influence entrepreneurial performance. This result is consistent with hypothesis14a, 14b.

Table 6. SEM Causal Path Coefficient and Hypothesis Verification

\begin{tabular}{|c|c|c|c|c|c|}
\hline $\begin{array}{l}\text { Research } \\
\text { Hypothesis }\end{array}$ & Causal path and its description & $\begin{array}{l}\text { Standard } \\
\text { path } \\
\text { coefficient }\end{array}$ & C.R. & $\begin{array}{c}\text { Significant } \\
\text { probability } \\
\mathrm{P} \text { values }\end{array}$ & $\begin{array}{l}\text { Test } \\
\text { Result }\end{array}$ \\
\hline $\mathrm{H} 1$ & $\begin{array}{l}\gamma_{\text {CR-EP: }} \text { Capital Resources }(\mathrm{CR}) \rightarrow \\
\text { Entrepreneurial Performances }(\mathrm{EP})\end{array}$ & $0.103^{* * * *}$ & 8.621 & 0.000 & accept \\
\hline $\mathrm{H} 2$ & $\begin{array}{l}\gamma_{\text {HR-EP: Human Resources(HR) }} \\
\rightarrow \text { Entrepreneurial Performances(EP) }\end{array}$ & $0.115^{* * *}$ & 9.577 & 0.000 & accept \\
\hline H3 & $\begin{array}{l}\gamma_{\text {MR-EP: Management Resource }(\mathrm{MR})} \\
\rightarrow \text { Entrepreneurial Performances }(\mathrm{EP})\end{array}$ & $0.043^{* * *}$ & 2.835 & 0.000 & accept \\
\hline $\mathrm{H} 4$ & $\begin{array}{l}\gamma_{\text {IR-EP: }} \text { Information Resources (IR) } \\
\rightarrow \text { Entrepreneurial Performances(EP) }\end{array}$ & $0.074^{* * *}$ & 7.492 & 0.000 & accept \\
\hline H5 & $\begin{array}{l}\gamma_{\text {TR-EP: }} \text { Technical Resources(TR) } \\
\rightarrow \text { Entrepreneurial Performances(EP) }\end{array}$ & $0.061^{* * *}$ & 6.153 & 0.000 & accept \\
\hline H6 & $\begin{array}{l}\gamma_{\text {PR-EP: }} \text { Policy Resources (PR) } \\
\rightarrow \text { Entrepreneurial Performances(EP) }\end{array}$ & $0.052^{* * * *}$ & 3.628 & 0.000 & accept \\
\hline $\mathrm{H} 7 \mathrm{a}$ & $\begin{array}{l}\gamma_{\text {CR-CLS: }} \text { Capital Resources }(C R) \rightarrow \\
\text { Capital leadership Strategy(CLS) }\end{array}$ & $0.189^{* * *}$ & 11.862 & 0.000 & accept \\
\hline $\mathrm{H} 7 \mathrm{~b}$ & $\begin{array}{l}\gamma_{\text {CR-DS: }} \text { Capital Resources(CR) } \\
\rightarrow \text { Differential Strategy (DS) }\end{array}$ & $0.242^{* * *}$ & 12.806 & 0.000 & accept \\
\hline $\mathrm{H} 8 \mathrm{a}$ & $\begin{array}{l}\gamma_{\text {HR-CLS: }} \text { Human Resources(HR) } \rightarrow \\
\text { Capital leadership Strategy(CLS) }\end{array}$ & $0.123^{* * *}$ & 10.176 & 0.000 & accept \\
\hline $\mathrm{H} 8 \mathrm{~b}$ & $\begin{array}{l}\gamma_{\text {HR-DS: Human Resources (HR) }} \\
\rightarrow \text { Differential Strategy(DS) }\end{array}$ & $0.331^{* * *}$ & 14.593 & 0.000 & accept \\
\hline $\mathrm{H} 9 \mathrm{a}$ & $\begin{array}{l}\gamma_{\text {MR-CLS: Management Resources (MR) }} \\
\rightarrow \text { Capital leadership Strategy(CLS) }\end{array}$ & $0.179^{* * *}$ & 11.420 & 0.000 & accept \\
\hline $\mathrm{H} 9 \mathrm{~b}$ & $\begin{array}{l}\gamma_{\text {MR-DS }} \text { Management Resources (MR) } \\
\rightarrow \text { Differential Strategy(DS) }\end{array}$ & 0.506 & 1.718 & 0.517 & reject \\
\hline $\mathrm{H} 10 \mathrm{a}$ & $\begin{array}{l}\gamma_{\text {IR-CLS: Information Resources(IR) }} \\
\rightarrow \text { Capital leadership Strategy(CLS) }\end{array}$ & $0.184^{* * *}$ & 11.695 & 0.000 & accept \\
\hline $\mathrm{H} 10 \mathrm{~b}$ & $\gamma_{\text {IR-DS: Information Resources(IR) }}$ & $0.138^{* * *}$ & 10.804 & 0.000 & accept \\
\hline
\end{tabular}




\begin{tabular}{|c|c|c|c|c|c|}
\hline & $\rightarrow$ Differential Strategy(DS) & & & & \\
\hline H11a & $\begin{array}{l}\gamma_{\text {TR-CLS: }} \text { Technology Resources(TR) } \\
\rightarrow \text { Capital leadership Strategy(CLS) }\end{array}$ & 0.482 & 1.659 & 0.623 & reject \\
\hline $\mathrm{H} 11 \mathrm{~b}$ & $\begin{array}{l}\gamma_{\text {TR-DS: Technology Resources(TR) }} \\
\rightarrow \text { Differential Strategy(DS) }\end{array}$ & $0.237^{* * *}$ & 12.526 & 0.000 & accept \\
\hline $\mathrm{H} 12 \mathrm{a}$ & $\begin{array}{l}\gamma_{\text {PR-CLS: }} \text { Policy Resources(PR) } \rightarrow \text { Capital } \\
\text { leadership Strategy(CLS) }\end{array}$ & 0.398 & 1.473 & 0.685 & reject \\
\hline $\mathrm{H} 12 \mathrm{~b}$ & $\begin{array}{l}\gamma_{\text {PR-DS: }} \text { Policy Resources(PR) } \rightarrow \\
\text { Differential Strategy(DS) } \\
\end{array}$ & $0.205^{* * *}$ & 12.178 & 0.000 & accept \\
\hline $\mathrm{H} 13 \mathrm{a}$ & $\begin{array}{l}\gamma_{\text {CLS -EP: }} \text { Capital leadership Strategy(CLS) } \\
\rightarrow \rightarrow \text { Entrepreneurial Performances(EP) }\end{array}$ & $0.257^{* * *}$ & 13.051 & 0.000 & accept \\
\hline $\mathrm{H} 13 \mathrm{~b}$ & $\begin{array}{l}\gamma_{\mathrm{DS}-\mathrm{EP}} \text { Differential Strategy(DS) } \\
\rightarrow \rightarrow \text { Entrepreneurial Performances(EP) }\end{array}$ & $0.282^{* * *}$ & 13.674 & 0.000 & accept \\
\hline
\end{tabular}

Note: * Stands for confidential level $\mathrm{P}<0.10$, ** Stands for confidential level $\mathrm{P}<0.05$, *** Stands for confidential level $\mathrm{P}<0.01$ 。

\subsection{Regression Analysis and Test Result of Environmental Dynamic Adjustment}

After statistical analysis of environmental dynamic adjustment using Multiple Linear Regression method with the help of SPSS 18.0 for Windows, we get the test results in table 7. As can be seen in table 7, the value of R2for model 8 is 0.805 . The adjusted value for R2 is 0.801 . The model fits the data well. The value of $F$ is 247.269 . P value is 0.000 , which is smaller than $1 \%$. The result shows that the regression is significant. The $\mathrm{t}$ statistics of constant in model 1 8 is significant under the 0.01 confidential level, which shows that constant is significant in these model and is non zero. Non-standardized regression coefficient value should be adopted. Controlled variables, contingency variables are not significant and thus these factors do not have significant impact on entrepreneurial performance. The non-standardized regression coefficients of capital resources, human resources, management resources, information resources, technology resources and policy resources are $0.223,0.235,0.102,0.164,0.131$, and 0.119 . Under 0.01 confidential levels, these factors have significant positive impact on the entrepreneurial performance, which is consistent with hypothesis 1, 2, 3, 4, 5, 6 .

As can be seen in model 8 from table7: (1) The non-standardized regression coefficients of capital resources, capital resources * environmental dynamics are 0.140, 0.075. Sum of these two coefficients is smaller than the non-standardized regression coefficient of capital resources in model $1(0.215<0.223)$. That is under 0.01 confidential level, environment dynamic exert negative adjustment function. The result is consistent with hypothesis 15. (2) The non-standardized regression coefficients of human resources, human resources * environmental dynamics are 0.149, 0.079. Sum of these two coefficients is smaller than the non-standardized regression coefficient of capital resources in model $1(0.228<0.235=$. That is under 0.01 confidential level, environment dynamic exert negative adjustment function. The result is consistent with hypothesis 16 . (3) The non-standardized regression coefficients of management resources, management resources * environmental dynamics are $0.058,0.037$. Sum of these two coefficients is smaller than the non-standardized regression coefficient of capital resources in model 1 $(0.095<0.102=$. That is under 0.01 confidential level, environment dynamic exert negative adjustment function. The result is consistent with hypothesis 17. (4) The nonstandardized regression coefficients of information resources, information resources $*$ environmental dynamics are $0.112,0.064$. Sum of these two coefficients is smaller than the non-standardized regression coefficient of capital resources in model $1(0.176>$ 0.164). That is under 0.01 confidential level, environment dynamic exert positive adjustment function. The result is not consistent with hypothesis 18. (5) The nonstandardized regression coefficients of technology resources, information resources * environmental dynamics are $0.084,0.053$. Sum of these two coefficients is smaller than 
the non-standardized regression coefficient of capital resources in model 1 . That is under 0.01 confidential level, environment dynamic exert positive adjustment function. The result is not consistent with hypothesis 19. (6)The non-standardized regression coefficients of policy resources, policy resources * environmental dynamics are 0.071, 0.042. Sum of these two coefficients is smaller than the non-standardized regression coefficient of capital resources in model $1(0.113<0.119)$. That is under 0.01 confidential level, environment dynamic exert negative adjustment function. The results are consistent with hypothesis 20 .

Table 7. Linear Regression and Significant Testing Result of Environmental Dynamics Adjustment

\begin{tabular}{|c|c|c|c|c|c|c|c|c|}
\hline Variable & Model1 & Model2 & Model3 & Model4 & Model5 & Model6 & Model7 & Model8 \\
\hline Constant & $3.125^{* * *}$ & $2.973^{* * * *}$ & $2.658^{* *}$ & $2.841^{* * * *}$ & $3.479^{* * *}$ & $3.283^{* * *}$ & $3.046^{* * *}$ & $2.734^{* * *}$ \\
\hline Enterprise Scale & .387 & .331 & .356 & .462 & .394 & .375 & .426 & .409 \\
\hline Enterprises Age & .365 & .427 & .384 & .401 & .358 & .392 & .457 & .436 \\
\hline Capital Resources & $.223^{* * * *}$ & $.142^{* * *}$ & $211^{* * * *}$ & $.215^{* * *}$ & $221^{* * * *}$ & $218^{* * *}$ & $.213^{* * *}$ & $.140^{* * * *}$ \\
\hline Human Resources & $.235^{* * *}$ & $.219^{* * *}$ & $.151^{* * * *}$ & $.223^{* * *}$ & $.229^{* * * *}$ & $.225^{* * *}$ & $232^{* * *}$ & $.149^{* * *}$ \\
\hline $\begin{array}{l}\text { Management } \\
\text { Resources }\end{array}$ & $.102^{* * *}$ & $.091^{* * * *}$ & $.087^{* * * *}$ & $.060^{* * *}$ & $.093^{* * *}$ & $.099^{* * *}$ & $.095^{* * * *}$ & $.058^{* * * *}$ \\
\hline $\begin{array}{l}\text { Information } \\
\text { Resources }\end{array}$ & $.164^{* * *}$ & $.159^{* * * *}$ & $.156^{* * *}$ & $.162^{* * * *}$ & $.115^{* * * *}$ & $.151^{* * *}$ & $.154^{* * *}$ & $.112^{* * * *}$ \\
\hline $\begin{array}{l}\text { Technology } \\
\text { Resources }\end{array}$ & $.131^{* * * *}$ & $.129^{* * *}$ & $.126^{* * * *}$ & $.118^{* * * *}$ & $.124^{* * * *}$ & $.085^{* * *}$ & $.121^{* * *}$ & $.084^{* * * *}$ \\
\hline Policy Resources & $.119^{* * *}$ & $.115^{* * *}$ & $.117^{* * * *}$ & $.113^{* * *}$ & $.106^{* * *}$ & $.108^{* * *}$ & $.073^{* * *}$ & $.071^{* * * *}$ \\
\hline $\begin{array}{c}\text { Environmental } \\
\text { dynamics }\end{array}$ & .382 & .437 & .416 & .449 & .471 & .524 & .508 & .493 \\
\hline $\begin{array}{c}\text { Capital } \\
\text { Resources*Environ } \\
\text { mental Dynamics }\end{array}$ & & $.078^{* * * *}$ & & & & & & $.075^{* * * *}$ \\
\hline $\begin{array}{c}\text { Human Resources* } \\
\text { Environmental } \\
\text { dynamics }\end{array}$ & & & $.081^{* * * *}$ & & & & & $.079^{* * * *}$ \\
\hline $\begin{array}{c}\text { Management } \\
\text { Resources*Environ } \\
\text { mental Dynamics }\end{array}$ & & & & $.039^{* * * *}$ & & & & $.037^{* * * *}$ \\
\hline $\begin{array}{c}\text { Information } \\
\text { Resources*Environ } \\
\text { mental Dynamics } \\
\end{array}$ & & & & & $.067^{* * * *}$ & & & $.064^{* * * *}$ \\
\hline $\begin{array}{c}\text { Technology } \\
\text { Resources* } \\
\text { Environmental } \\
\text { dynamics } \\
\end{array}$ & & & & & & $.056^{* * *}$ & & $.053^{* * * *}$ \\
\hline $\begin{array}{c}\text { Policy } \\
\text { Resources*Environ } \\
\text { mental Dynamics }\end{array}$ & & & & & & & $.044^{* * *}$ & $.042^{* * * *}$ \\
\hline $\mathbf{R}^{2}$ & .704 & .753 & .764 & .745 & .759 & .785 & .778 & .805 \\
\hline Adjusted $\mathbf{R}^{2}$ & .699 & .748 & .759 & .741 & .755 & .781 & .773 & .801 \\
\hline $\mathbf{F}$ & 316.271 & 276.864 & 269.106 & $284_{* * * *} .493$ & 261.762 & 265.378 & $\begin{array}{l}291.61 \\
2^{* * * *}\end{array}$ & 247.269 \\
\hline
\end{tabular}

Note: (1).N=361, ${ }^{*},{ }^{* *},{ }^{* * *}$ stand for confidential level respectively $\mathrm{P}<0.10, \mathrm{P}<0.05, \mathrm{P}<0.01$; (2)Dependent

Variable: entrepreneural performance

\section{Further Discussion over Test Result of Hypothesis}

Causal path of capital resources include capital resources $(\mathrm{CR}) \rightarrow$ entrepreneurial performance(EP), capital resources $(\mathrm{CR}) \rightarrow$ cost leadership strategy(CLS), capital resources $(C R) \rightarrow$ differential strategy $(D S)$, and test results are $\gamma_{\text {CR-EP }}=0.103, \gamma_{\text {CR-CLS }}=0.189$, $\gamma_{\text {CR-DS }}=0.242$, P value are all 0.000 . Hypothesis $1,7 \mathrm{a}, 7 \mathrm{~b}$ stand, capital resources have the 
second largest positive impact on the entrepreneurial performance, and have positive impact on cost leadership strategy and differential strategy. Indirect casual path includes $\mathrm{CR} \rightarrow \mathrm{CLS} \rightarrow \mathrm{EP}, \quad \mathrm{CR} \rightarrow \mathrm{DS} \rightarrow \mathrm{EP}, \quad$ test results are $\gamma_{\mathrm{CR}-\mathrm{CLS}}=0.189, \gamma_{\mathrm{CR}-\mathrm{DS}}=0.242, \gamma_{\text {CLS }}$ $\mathrm{ED}=0.257, \gamma_{\mathrm{DS}-\mathrm{ED}}=0.282$. $\mathrm{P}$ values are all 0.000 . Assume hypothesis $7 \mathrm{a}, 7 \mathrm{~b}, 13 \mathrm{a}, 13 \mathrm{~b}$ stand, then capital resources have positive impact on cost leadership strategy and differential strategy, also cost leadership strategy and differential strategy have positive impact on entrepreneurial performance. Thus, we could draw the conclusion that entrepreneurial strategy exerts intermediary functions between entrepreneurial resources and entrepreneurial performance. Hypothesis 14a and 14b stand, entrepreneurs and their teams should integrate their own interest and the development of enterprises, use self-fund capital for starting business and prepare for enough and flexible cash flows. At the same time entrepreneurs should enrich their external capital resources input channels, such as fund, loan and investment and thus improve the positive impact on entrepreneurial performance. What's more, entrepreneurs should also make the best use of capital by implementing cost leadership strategy and differential strategy, and thus promote the efficiency and result of entrepreneurial activities.

Causal path of human resources include human resources $(\mathrm{HR}) \rightarrow$ entrepreneurial performance(EP), human resources(HR) $\rightarrow$ cost leadership strategy(CLS), human resources $(\mathrm{HR}) \rightarrow$ differential strategy(DS), test results are $\gamma_{\mathrm{HR}-\mathrm{EP}}=0.115, \gamma_{\mathrm{HR}-\mathrm{CLS}}=0.123$, $\gamma_{\text {HR-DS }}=0.331$. P values are all 0.000. Hypothesis $1,8 \mathrm{a}, 8 \mathrm{~b}$ stand, human resources have the largest positive impact on the entrepreneurial performance, and have positive impact on cost leadership strategy and differential strategy. Indirect casual path includes $\mathrm{HR} \rightarrow \mathrm{CLS} \rightarrow \mathrm{EP}, \mathrm{HR} \rightarrow \mathrm{DS} \rightarrow \mathrm{EP}$, test results $\gamma_{\mathrm{HR}-\mathrm{CLS}}=0.123, \gamma_{\mathrm{HR}-\mathrm{DS}}=0.331, \gamma_{\mathrm{CLS}-\mathrm{ED}}=0.257$, $\gamma_{\mathrm{DS}-\mathrm{ED}}=0.282$. $\mathrm{P}$ values are all 0.000 . Assume hypothesis $8 \mathrm{a}, 8 \mathrm{~b}, 13 \mathrm{a}, 13 \mathrm{~b}$ stand, then human resources have positive impact on cost leadership strategy and differential strategy, also cost leadership strategy and differential strategy have positive impact on entrepreneurial performance. Thus, we could draw the conclusion that entrepreneurial strategy exerts intermediary functions between entrepreneurial resources and entrepreneurial performance. Hypothesis 14a and 14b stand, entrepreneurial enterprises should pay highly attention to the positive impact brought by human resources. Entrepreneurs should try to attract and employ employees with a variety of knowledge base, background of professional technics, high education background and high quality management skills. Also, they need to recruit members with previous working or entrepreneurial experience, and make the best use of their knowledge, technology and social capital that accumulated at work. Trainings for the employees are also very important. Entrepreneurial companies should try best to cultivate talents with great vision, innovation awareness and strong innovation ability and to build up teams with their own entrepreneurship spirit. And thus promote the positive impact of human resources on entrepreneurial performance, optimize the use of talents, promote the formulation and implementation of cost leadership strategy or differential strategy and thus improve entrepreneurial performance.

Causal path of management resources include management resources(MR) $\rightarrow$ entrepreneurial performance $(\mathrm{EP})$, management resources(MR) $\rightarrow$ cost leadership strategy(CLS), management resources(MR) $\rightarrow$ differential strategy(DS), test results are $\gamma_{\text {MR-EP }}=0.043, \gamma_{\text {MR-CLS }}=0.179, \gamma_{\text {MR-DS }}=0.506$. P values are $0.000,0.000,0.517$. Hypothesis $1,7 \mathrm{a}$ stand, $7 \mathrm{~b}$ fail. Management resources have the least direct positive impact on the entrepreneurial performance, and have positive impact on cost leadership strategy, but have no influence on differential strategy. Indirect casual path includes MR $\rightarrow C L S \rightarrow E P$, $\mathrm{MR} \rightarrow \mathrm{DS} \rightarrow \mathrm{EP}$, test results $\gamma_{\mathrm{MR}-\mathrm{CLS}}=0.179, \gamma_{\mathrm{MR}-\mathrm{DS}}=0.506, \gamma_{\mathrm{CLS}-\mathrm{ED}}=0.257, \gamma_{\mathrm{DS}-\mathrm{ED}}=0.282 . \mathrm{P}$ values are $0.000,0.506,0.000,0.000$. Hypothesis $7 \mathrm{a}, 13 \mathrm{a}, 13 \mathrm{~b}$ stand, but $7 \mathrm{~b}$ fails. Management resources have positive impact on cost leadership strategy, but have no influence on differential strategy. Also cost leadership strategy and differential strategy 
have positive impact on entrepreneurial performance. Thus (,) we could draw the conclusion that entrepreneurial strategy exerts intermediary functions between entrepreneurial resources and entrepreneurial performance. Hypothesis 14a and 14b stand. Entrepreneurial enterprises should pay highly attention to the positive impact brought by management resources. For entrepreneurial enterprises, the least but important positive impact of management resources cannot be ignored. They should try their best to increase the influential power of management resources. In entrepreneurial practice, by sharing management knowledge and entrepreneurial experience of entrepreneurial staff, building advanced entrepreneurial management knowledge system, and gaining cost advantage from all possible external management consulting and strategy service resources, enterprises can strengthen the positive impact of management resources on entrepreneurial performance. Also it is very important to share the management resource within entrepreneurial companies. Entrepreneurial companies should push the implementation of cost leadership strategy of "facing competition actively, enrich and penetrate the market by providing overflow product and service" to improve entrepreneurial performance.

Causal path of information resources include information resources (IR) $\rightarrow$ entrepreneurial performance $(\mathrm{EP})$, information resources(IR) $\rightarrow$ cost leadership strategy $(C L S)$, information resources(IR) $\rightarrow$ differential strategy(DS), test results are $\gamma_{\text {IR-EP }}=0.074$, $\gamma_{\mathrm{IR}-\mathrm{CLS}}=0.184, \gamma_{\mathrm{IR}-\mathrm{DS}}=0.138$. $\mathrm{P}$ values are all 0.000 . Hypothesis $1,10 \mathrm{a}$ and $10 \mathrm{~b}$ stand. Information resources have direct positive impact on the entrepreneurial performance, and have positive impact on cost leadership strategy and differential strategy. Indirect casual path includes $\mathrm{IR} \rightarrow \mathrm{CLS} \rightarrow \mathrm{EP}, \mathrm{IR} \rightarrow \mathrm{DS} \rightarrow \mathrm{EP}$, test results $\gamma_{\mathrm{IR}-\mathrm{CLS}}=0.184, \gamma_{\mathrm{IR}-\mathrm{DS}}=0.138, \gamma_{\mathrm{CLS}-}$ $\mathrm{ED}=0.257, \gamma_{\mathrm{DS}-\mathrm{ED}}=0.282$. $\mathrm{P}$ values are all 0.000 . Hypothesis $10 \mathrm{a}, 10 \mathrm{~b}, 13 \mathrm{a}, 13 \mathrm{bstand}$. Information resources have positive impact on cost leadership strategy, but have no influence on differential strategy. Also cost leadership strategy and differential strategy have positive impact on entrepreneurial performance. Thus we could draw the conclusion that entrepreneurial strategy exerts intermediary functions between entrepreneurial resources and entrepreneurial performance. Hypothesis $14 \mathrm{a}$ and $14 \mathrm{~b}$ stand. Entrepreneurial enterprises should pay highly attention to the positive impact brought by information resources. Entrepreneurial companies should try their best to gain the industry and exclusive technology information at the start stage of their business. They also need to seek and dive deep into competitor's fundamental information, and capture the market opportunities and consumer needs. At the same time, entrepreneurial enterprises should fully understand and be familiar with the information of research, purchasing, producing, marketing and service to strengthen the positive impact of information resources on performance. With the help of further integration of information resources and implementation of cost leadership strategy and differential strategy, entrepreneurial performance could be improved.

Causal path of technology resources include technology resources(TR) $\rightarrow$ entrepreneurial performance $(\mathrm{EP}), \quad$ technology $\quad$ resources(TR) $\rightarrow$ cost leadership strategy(CLS), technology resources(TR) $\rightarrow$ differential strategy(DS), test results are $\gamma_{\mathrm{TR}-}$ ${ }_{\mathrm{EP}}=0.061, \gamma_{\mathrm{TR}-\mathrm{CLS}}=0.482, \gamma_{\mathrm{TR}-\mathrm{DS}}=0.237$. $\mathrm{P}$ values are $0.000,0.623,0.000$. Hypothesis 1 , $11 \mathrm{~b}$ stand but hypothesis 11a fails. Technology resources have direct positive impact on the entrepreneurial performance, and have positive impact on differential strategy but have little impact on cost leadership strategy. Indirect casual path includes $\mathrm{TR} \rightarrow \mathrm{CLS} \rightarrow \mathrm{EP}, \quad \mathrm{TR} \rightarrow \mathrm{DS} \rightarrow \mathrm{EP}, \quad$ test $\quad \mathrm{CLS}=0.482, \quad \gamma_{\mathrm{TR}-\mathrm{DS}}=0.237, \quad \gamma_{\mathrm{CLS}-\mathrm{ED}}=0.257, \gamma_{\mathrm{DS}}$ ${ }_{E D}=0.282$. $P$ values are $0.623,0.000,0.000,0.000$. Hypothesis $11 b, 13 a, 13 b s t a n d$, but 11a does not stand. Technology resources have positive impact on cost leadership strategy, but have no influence on differential strategy. Also cost leadership strategy and differential strategy have positive impact on entrepreneurial performance. Thus we could draw the conclusion that entrepreneurial strategy exerts intermediary functions between entrepreneurial resources and entrepreneurial performance. Hypothesis 14a and 14b stand. 
Entrepreneurial enterprises should pay highly attention to the positive impact brought by technology resources. Therefore, entrepreneurial companies rely on technology resources for the supporting function of high and new techniques. In specific entrepreneurial practice, entrepreneurs should make every effort to get some important technology results and patents to build the conversional platform of technology resources, and thus contribute to the commercialization and marketization of technical product. Also entrepreneurial enterprises should actively obtain multiple supporting technologies to strengthen the positive impact of technology resources on entrepreneurial performance and to promote the formulation and implementation of "Focusing on market segmentation, precise consumer target and differential pricing, achieving differential competition advantage by encouraging innovation of product and technology" strategy to promote the efficiency and result of entrepreneurial activities to the greatest extent.

Hypothesis 12b, 13a, 13b stand, but 12a does not stand. Technology resources have positive impact on differential strategy, but have no influence on cost leadership strategy. Also cost leadership strategy and differential strategy have positive impact on entrepreneurial performance. Thus we could draw the conclusion that entrepreneurial strategy exerts intermediary functions between entrepreneurial resources and entrepreneurial performance. Hypothesis 14a and 14b stand. Entrepreneurial enterprises should pay highly attention to the positive impact brought by policy resources. In real entrepreneurial activities, entrepreneurial enterprises should seek policy support and preferential of investing and financing, especially the policy support of innovation and developing new technology. Also startups should make the best use of existing policies that encourage innovation and entrepreneurial activities, including opportunityentrepreneurial policy, practical entrepreneurship education counseling, entrepreneurial talent introduction policy and training policy and superiority. Policy resources have direct positive impact on entrepreneurial performance. Policy resources can also promote entrepreneurial strategy by obtaining government support on innovation activities and technology developing strategy and implementing "Focusing on market segmentation, precise consumer target and differential pricing, achieving differential competition advantage by encouraging innovation of product and technology" differential strategies.

\section{Conclusions and Expectations}

After reviewing essays, building models, bringing up hypothesis, logistic test, collecting and calculating statistics, this paper draw the following conclusions:

Entrepreneurial resources like capital resources, management resources, management resources, information resources, technology resources, policy resources have positive and direct impact on the entrepreneurial performance. Among all these resources, management resource is the most important factor for it to exert greatest positive influence to the entrepreneurial performance. Capital resource is the second largest influential factor and the necessity of entrepreneurial activities. Then here come the information resources, policy resources and management resources. Although management resources only input little incentives, the significance of the positive impact of management resources cannot be ignored.

Capital resources, management resources, management resources, information resources, technology resources and policy resources also have positive impact on entrepreneurial strategy. The richer the entrepreneurial resources are, the more beneficial it is to promote design and action of the entrepreneurial strategy. In particular, the richer the capital resources, management resources and information resources are, the more beneficial it is to promote cost leadership strategy and differential strategy. The richer the management resources are, the more beneficial it is to promote cost leadership strategy. That is, given the sufficient information resources, entrepreneurial enterprises tend to choose and implement cost leadership strategy. Given sufficient technology and good 
policy resources, entrepreneurial enterprises tend to choose and implement differential strategy. What's more, cost leadership strategy and differential strategy both have positive impact on the entrepreneurial performance. That is, the better these two strategies are carried out, the better the entrepreneurial performance is. The multi-influence of these two strategies is greater than that of each. Entrepreneurial resources have impact on entrepreneurial strategies. Entrepreneurial strategies affect entrepreneurial performance. Entrepreneurial resources also have directly impact on the entrepreneurial performance. From the above relationship, this paper draws the conclusion that entrepreneurial strategies exert partly intermediary function in the mechanism of entrepreneurial performance.

Environmental dynamic itself is not the influential factor of the entrepreneurial performance, and thus have no significant impact on the entrepreneurial performance. No matter the environment is dynamic or stable, it cannot significantly positively or negatively influence the entrepreneurial performance. Environment exerts moderate functions in the relationships between entrepreneurial resources and entrepreneurial performance. Environment dynamic exert negative moderate functions whilst capital resources, management resources, management resources and policy resources affect entrepreneurial performance. That is in highly dynamic environment, the variation of environment and uncertainty factors would bring negative impact, which makes it easier to weaken the positive impact of capital resources, management resources, management resources and policy resources on entrepreneurial performance. However, environment dynamics exert positive impact on information resources and technology resources. That is, technology and information resources matter more in a more flexible market and accelerate the spread of new technology and knowledge. In highly dynamic market, the chances of innovation and developing new products increase. Besides, the age and the scale of entrepreneurial enterprises do not have significantly positive impact on the performance of entrepreneurial enterprises. The age and the scale of enterprises are both uncontrollable factors. In this research, the interviewed sample size is not big enough, and the scale of interviewed companies is not large. In this case, the age and the scale of enterprises could hardly have the positive impact on the entrepreneurial performance.

\section{Acknowledgments}

The authors are grateful for research support from MOE (Ministry of Education in China) Project of Humanities and Social Sciences (Grant No. 14YJC790167), Scientific Research Staring Foundation for the Returned Overseas Chinese Scholars Ministry of Education of China (Grant No. (2013)1792), project of Educational Commission of Zhejiang Province in China (Grant No. Y201432409) and AFR (Academy of Financial Research of Zhejiang Province) financial discipline development project (Grant No. XK14007).

\section{Reference}

[1] A. L. Stinchcombe, "Social Structure and Organizations", March, J. G.(ed), Handbook of organizations, Chicago: Rand McNally, (1965).

[2] J. Pfeffer and G. R. Salancik, "The Extemal Control of Organizations: A Resource Dependence Perspective", New York: Harper and Row, (1978).

[3] G. N. Chandler and S. H. Hanks, "Market Attractiveness, Resource-based Capabilities, Venture Strategies, and Venture Performance", Journal of Business Venturing, vol. 9, (1994), pp. 331-349.

[4] A. Bhide, "The Origin and Evolution of New Businesses", New York: Oxford University Press, (2000).

[5] S. A. Shane and S. Venkataraman, "The Promise of Entrepreneurship as A Field of Research", Academy of Management Review, vol. 25, (2000), pp. 217-226.

[6] J. T. Eckhardt and S. A. Shane, "Opportunities and Entrepreneurship", Journal of Management, vol. 29, (2003), pp. 333-349.

[7] S. A. Zahra and G. George, "International Entrepreneurship: The Current Status of The Field and Future Research Agenda 2002”, Oxford: Blackwell Publishers, (2002). 
[8] M. G. Colombo and L. Grili, "Founders Management Capital and The Growth of New TechnologyBased Firms: A Competence-based View", Research Policy, vol. 34, (2005), pp. 795-816.

[9] J. A. Timmons, "New Venture Creation (5ed.)", New York: McGraw-Hill, (1999).

[10] D. Ucbasaran, P. Westhead and M. Wright, "The Focus of Entrepreneurial Research: Contextual and Process Issues", Entrepreneurship Theory and Practice, vol. 26, (2001), pp. 57-80.

[11] T. Elfring and W. Hulsink, "Networks in Entrepreneurship: The Case of High-Technology Firms", Small Business Economics, vol. 21, (2003), pp. 409-422.

[12] K. Hmieleski and A. Corbett, "Proclivity for Improvisation as A Predictor of Entrepreneurial Intentions", Journal of Small Business Management, vol. 44, (2006), pp. 45-63.

[13] S. A. Zahra, "Environment, Corporate Entrepreneurship and Financial Performance: A Taxonomic Approach", Journal of Business Venturing, vol. 8, (1993), pp. 319-340.

[14] G. T. Lumpkin and G. G. Dess, "Clarifying the Entrepreneurial Orientation Construct and Linking It to Performance", The Academy of Management Review, vol. 21, (1996), pp. 135-172.

[15] G. T. Lumpkin and G. G. Dess, "Linking Two Dimensions of Entrepreneurial Orientation to Firm Performance: The Moderating Role of Environment and Industry Life Cycle", Journal of Business Venturing, vol. 16, (2001), pp. 429-451.

[16] G. T. Lumpkin and C. Sloat, "Do Family Firms Have An Entrepreneurial Orientation?", Frontiers of Entrepreneurship Research, vol. 14, (2001), pp. 347-365.

[17] P. M. Kreiser, L. D. Marino and K. M. Weaver, "Reassessing the Environment-EO Link: The Impact of Environmental Hostility on The Dimensions of Entrepreneurial Orientation", Academy of Management Proceedings, (2002).

[18] J. Wiklund and D. Shepherd, "Entrepreneurial Orientation and Small Business Performance: A Configurational Approach", Journal of Business Venturing, vol. 20, (2005), pp. 71-91.

[19] M. D. Ensley, C. L. Pearce and K. M. Hmieleski, "The Moderating Effect of Environmental Dynamic on The Relationship Between Entrepreneur Leadership Behavior and New Venture Performance", Journal of Business Venturing, vol. 21, (2006), pp. 243-263.

[20] L. Song, "The Gaining and Integrating of Entrepreneurial Resources: A Perspective of Entrepreneurial Process", Inquiry into Economic Issues, vol. 6, (2007), pp. 166-169.

[21] M. Yao, J. Huang and X. Zhang, "Evaluation Study on Necessity Entrepreneurship Performance Based on Key Entrepreneurial Factors", Modernization of Management, vol. 4, (2008), pp. 16-18.

[22] M. E. Porter, "Competitive Strategy: Techniques for Analyzing Industries and Competition", New York: Free Press, (1980).

[23] Jr. H. F. Hair, R. E Anderson, R. L. Tatham and W. C. Black, "Multivariate Data Analysis", London: Prentice-Hall, (1998)

[24] R. P. Bagozzi, Y. Yi and S. Singh, "On The Use of Structural Equation Models in Experimental Designs: Two Extensions”, International Journal of Research in Marketing, vol. 8, (1991), pp. 125-140.

[25] L. Hu and P. M. Bentler, "Fit Indices in Covariance Structure Modeling: Sensitivity to Underparameterizedmodel Misspecification”, Psychological Methods, vol. 3, (1998), pp. 424-453.

[26] P. M. Bentler and D. G. Bonett, "Significance Tests and Goodness of Fit in The Analysis of Covariance Structures", Psychological Bulletin, vol. 88, (1980), pp. 588-606.

[27] B. M. Byrne, "Structural Equation Modeling With LISREL, PRELIS, and SIMPLIS: Basic Concepts, Applications, and Programming", New Jersey: Lawrence Erlbaum Associates, Inc, Publishers, (1998).

[28] M. W. Browne and R. Cudeck, "Alternative Ways of Assessing". Model Fit Sociological Methods Research, vol. 21, (1992), pp. 230-258. 
International Journal of Security and Its Applications

Vol. 10, No. 3 (2016) 